\title{
Pathological changes inducing by S.aureus in immunodeficiency mice immunized with Soluble Culture Filtrate S.aureus Antigens (SCFAgs).
}

\author{
H. H. K.AL-Byatee, \\ M. J. A.AL- Jubory.
}

Coll. of Vet. Med./ Unive. of Tikrit Coll. of Vet. Med./ Unive. of Baghdad

\section{Abstract}

In order to determine the influence of Soluble Culture Filtrate S.aureus Antigens (SCFAgs) on S.aureus infection in Mitomicin c immunosupression mice, seventy four white mice, both sex,7-8 weeks age were divided randomly into five groups..$^{\text {st }}$ group $(\mathrm{n}=16)$ was immunized with $0.4 \mathrm{ml}$ of S.aureus CFSAgs (concentration of protein $(4.2 \mathrm{mg} / \mathrm{ml}$ ) , $\mathrm{i} / \mathrm{p}$ two doses, 2 weeks intervals. $2^{\text {nd }} \operatorname{group}(\mathrm{n}=16)$ was injected with mitomycine $\mathrm{C},(1 \mathrm{mg} / \mathrm{kg} \mathrm{B} . \mathrm{W}) \mathrm{I} / \mathrm{p}$ three time /week for 4 weeks. $3^{\text {ed }}$ group $(n=16)$ was immunized with CFSAgs as 1 st group and treated with mitomycin as $2^{\text {nd }}$ group. $4^{\text {th }}$ group $(\mathrm{n}=10)$ was inoculated with $(0.4 \mathrm{ml}) \mathrm{I} / \mathrm{P}$ with $1 \mathrm{X} 10^{9}$ CFU/ML of viable virulent. S.aureus and was served as control positive group. $5^{\text {th }}$ group $(\mathrm{n}=16)$ was inoculated with $0.5 \mathrm{ml}$ sterile normal saline. Cellular and humoral immune response were recorded at 28-30 day post immunization, skin test and passive heam agglutination test respectively, then all animals of immunized and treatment groups were challenge with $S$,aureus as control positive group. The results explained that animals treatment with MMC were died during (18) hrs post inoculation with virulent viable S.aureus with very heavy bacterial isolation, animal of control positive group were died at( 24)hrs post infection with heavy bacterial isolation The results revealed that immunization with CFSAgs elicited both humoral and cellular immune responses, the level values of both arms of immune response were lower animal treatment with MMC, Severe pathological lesions were seen in examined organs of control positive group but these lesions are more extensive in animal treatment with MMC. The main lesions in examined organs of these animals are suppurative inflammation, congestion, apoptosis and necrosis.. We conclusion that MMC induce immunosuppression condition and immunization with CFSAgs can improve the immune responses in the animals that are suffering from immunosuppression.

KEYWORDS. S.aureus. SCFSAgs. SSSAgs. Mitomycin C .

\section{Introduction}

Chemotherapy primarily refers to the treatment of cancer with an antineoplastic drug such as mitomycin $\mathrm{C}$ or with a combination of such drugs into a standardized treatment regimen. Certain chemotherapy agents also have a role in the treatment of other conditions, and they act by killing cells that divide rapidly such as cancer cells and other cells that divided rapidly under normal circumstances e.g. cells in the bone marrow, digestive tract, and hair follicles and may be lead to immunosuppression (1). In 2005, methicillin-resistant S. aureus caused 94,360 severe invasive infections and resulted in 18,650 deaths in the US, exceeding the annual number of deaths in the US caused by increasing immunodeficiency diseases such as HIV/AID ,tuberculosis, and viral hepatitis combined (2). Different type of S.aureus antigens were used previously as a vaccine but these Ags produced partial protection(3).In the present study we attested to determine the influence of SCFSAgs on S.aureus infection in MMC immunedepression mice. 


\section{Materials and Methods}

\section{S.aureus strains:}

S.aureus were obtained from unit of zoonotic disease, Collage of Vet. Medicine and biochemical tests were used for Confirmation of this microorganism according to (4).

Preparation of S.aureus Antigens:

Culture filtrated S.aureus antigens (CFSAgs):

1. S.aureus was cultured on 15 nutrient agar plates and incubated at $37 \mathrm{c}^{\circ}$ for $24 \mathrm{hrs}$ then harvested) by PBS 7.2, and the bacterial suspension was centrifuged at $3000 \mathrm{rpm} 4{ }^{\circ} \mathrm{C} / 30$ minutes. The supernatant was taken in sterile method and consider as(CFSAgs). The total protein concentration of this antigen was measured according to Biuret procedure $(4.2 \mathrm{mg} / \mathrm{ml})$. Than part of this supernatant solution was cold centrifuged at 23000rpm for (30) minutes ,the supernatant was consider as soluble culture filtrate staph antigen (SCFSAgs). The supernatant fluid was examined by gram stain and culturing on blood agar to confirm sterility of these antigen.

Whole S.aureus Sonicated Ag. (WSS Ag):

It was prepared as follow (Mitove et al., 1992):

2. S.aureus cultured on nutrient agar, incubated at $37{ }^{\circ} \mathrm{C}$ for $24 \mathrm{hrs}$. and harvested by PBS 7.2, centrifuged at $3000 \mathrm{rpm} 4{ }^{\circ} \mathrm{C} / 30$ minutes then washed the precipitate three times with PBS, and the precipitate was resuspended with PBS and put in the universal tube.

3. Sonication: the universal tube that contained S.aureus suspension was placed in the ultrasonicator (type Karl Klob - Germany) at 12 Peak with 2 minutes intervals between them, for 30 minutes in cold environment (ice). The sonicated suspension was centrifuged at $23000 \mathrm{rpm}$ for 30 minutes.
4. The supernatant fluid was examined by gram stain and culturing on blood agar to confirm sterility of these antigen.

5. The total protein concentration of this antigen, which measured according to Biuret procedure $16 \mathrm{mg} / \mathrm{ml}$ and it was diluted to become $0.5 \mathrm{mg} / \mathrm{ml}$ this antigens was considered as soluble sonicated staph antigens(SSSAgs)

Determination of the virulent and Challenge Dose S.aureus:

S.aureus cultured on nutrient agar and incubated at $37{ }^{\circ} \mathrm{C}$ for $24 \mathrm{hrs}$. Two mice were inoculated $\mathrm{I} / \mathrm{P}$ with $0.2 \mathrm{ml}$ of bacterial growth ,the animals were scarified at $24 \mathrm{hrs}$ post inoculated and pieces from internal organs were culture on the blood agar for 24 hrs at $37 \mathrm{c}^{\circ}$ and this process was recurrent until the inoculated animals were dead during 24 hrs. 12 mice both sex were divided into three equal group and they were inoculated with $0.2 \mathrm{ml}$ of bacterial suspension containing $1 \times 10^{8}, 1 \times 10^{9}$ and $1 \times 10^{10} \mathrm{CFU}$ of virulent $\mathrm{S}$.aureus respectively and we recorded the number of dead animal during 24- $48 \mathrm{hrs}$ post inoculation. The dose which killed half number of inoculated animal was consider as a challenge dose ( $\left.1 \times 10^{9} \mathrm{CFU} / \mathrm{ML}\right)$ (5). The preparation of the bacterial suspension of the counting was made using (5).

\section{Preparation of Mitomycine C:}

Stock solution was prepared by dissolving 2 $\mathrm{mg}$ of mitomycin in $(20 \mathrm{ml})$ of sterilized D.W for giving the concentration $(2000 \mu \mathrm{g} / \mathrm{ml})$, and stored at $4{ }^{\circ} \mathrm{C}$ away from light .

\section{Experimental Design:}

One seventy four mice, both sex , 7-8 weeks old were divided randomly into (5) groups and treated as the following: $1.1^{\mathrm{st}} \operatorname{group}(\mathrm{n}=16)$ was immunized with $0.4 \mathrm{ml}$ of S.aureus CFSAgs (concentration of protein $(4.2 \mathrm{mg} / \mathrm{ml})$,i $/ \mathrm{p}$ two doses, 2 weeks intervals. 
$\begin{array}{llll}\text { AL-Qadisiya Journal of Vet.Med.Sci. } & \text { Vol./12 } & \text { No./1 }\end{array}$

$2.2^{\text {nd }} \quad \operatorname{group}(\mathrm{n}=16) \quad$ was injected with mitomycine $\mathrm{C},(1 \mathrm{mg} / \mathrm{kg} \mathrm{B.W}) \mathrm{I} / \mathrm{p}$ three time /week for 4 weeks.

$3-3^{\text {ed }}$ group $(n=16)$ was immunized with CFSAgs as 1st group and treated with mitomycin as $2^{\text {nd }}$ group.

$4-4^{\text {th }}$ group $(n=10)$ was inoculated with $(0.4 \mathrm{ml}) \mathrm{I} / \mathrm{P}$ with $1 \mathrm{X} 10^{9} \mathrm{CFU} / \mathrm{ML}$ of viable virulent. S.aureus and was served as control positive group.

$5-5^{\text {th }}$ group $(n=16)$ was inoculated with $0.5 \mathrm{ml}$ sterile normal saline.

Cellular immune response was detected at 28 days post immunization with skin test and at day 30 post immunization ,6 animals from $1^{\text {st }}, 2^{\text {nd }}, 3^{\text {ed }}, 5^{\text {th }}$ groups were sacrificed for collection of blood and to determine the homural immune response, then remain

\section{Results and Discussion}

\section{Immunization:}

\section{Skin and Passive Heamagglutination Test:}

At $24 \mathrm{hr}$ post testing, The results showed that the mean values of skin thickness against SCFSAgsand against SSSAgs $(0.44 \pm 0.01,0.30 \pm 0.01)$ were high in $1^{\text {st }}$ group as compared with $3^{\text {ed }}$ group 0.28 $\pm 0.02,0.15 \pm 0.02$ ) respectively. At $48 \mathrm{hr}$ animals of $1^{\text {st }}, 2^{\text {nd }}, 3^{\text {rd }}, 4^{\text {th }} 5^{\text {th }}$, groups were challenge I/P with $1 \mathrm{X} 10^{9} \mathrm{CFU} / \mathrm{ML}$ of viable virulent S.aureus. Five animals from each group were sacrificed at 3 and ,10 days post challenge and post-mortem examination was done, pieces from internal organs were taken for bacterial isolation and other pieces were fixed in $10 \%$ neutrals buffer formaldehyde (72 hrs) for histopathological examination.

\section{Plan of study:}

Delayed Type Hypersensitivity Test (DTH):

The test Was conducted according to (6).

Passive Hem agglutination Test (PHA Test)

The test Was conducted according to(7).

post examination,the mean values of DTH against both SCFSAgs and SSSAgs were decline in $1^{\text {st }}$ group $(0.42 \pm 0.01,0.27 \pm$ $0.07)$ and in $5^{\text {th }}$ group $(0.26 \pm 0.02,0.15 \pm$ $0.02)$ respectively(table: 1$)$. The results of passive haemagglutination examination revealed the serum Abs titers in $1^{\text {st }}$ group $(35.2 \pm 7.8)$ higher than in $3^{\text {ed }}$ group $(17.6 \pm$ 3.91) (table: 2).

Table (l) mean and standard error of skin test in differences immunized groups aginst (CFSAgs) and (SSSAgs) at 24 and 48 hours.

\begin{tabular}{|c|c|c|c|c|}
\hline & \multicolumn{2}{|c|}{ CFSAgs } & \multicolumn{2}{|c|}{ SSSAgs } \\
\hline & $24 \mathrm{hrs}$ & $48 \mathrm{hrs}$ & $24 \mathrm{hrs}$ & $48 \mathrm{hrs}$ \\
\hline$\overline{\mathrm{Gl}}$ & $0.44 \pm 0.01 \mathrm{Mm} \mathrm{C}$ & $0.42 \pm 0.01 \mathrm{Mm} \mathrm{c}$ & $0.30 \pm 0.01 \mathrm{Mm} \mathrm{c}$ & $\begin{array}{c}0.27 \pm 0.07 \mathrm{Mm} \\
\mathrm{c}\end{array}$ \\
\hline G3 & $0.28 \pm 0.02 \mathrm{Mm} \mathrm{D}$ & $0.26 \pm 0.02 \mathrm{Mm} \mathrm{d}$ & $0.15 \pm 0.02 \mathrm{Mm} \mathrm{d}$ & $\begin{array}{c}0.15 \pm 0.02 \mathrm{Mm} \\
\mathrm{d}\end{array}$ \\
\hline G5 & & 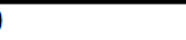 & 0 & \\
\hline
\end{tabular}

The different letters in different groups=significant difference at $\mathrm{P} \leq 0.05$

SCFS Ags = soluble culture filtrated S. aureus antigens $\quad \mathrm{G}=$ name of group $\mathrm{SE}$ =stander error $\mathrm{Me}=$ mean $\mathrm{Mm}=$ micrometer SSSAgs = soluble sonicated

S.aureus antigens
Table(2): mean and standard error of titer Abs in Passive Hemagglutination Test in immunized groups and control group at 30 days.

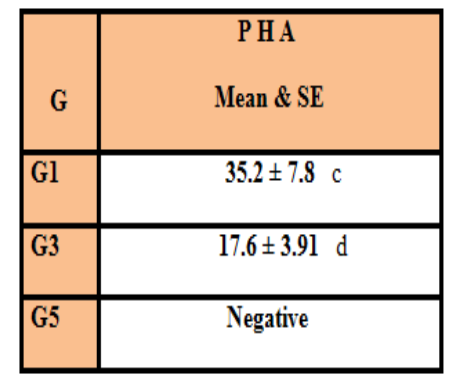

The different letters in different group $=$ significant differences at $P \leq 0.05$ PH A = Passive Hemagglutination Test $\mathrm{G}=$ name of group

$\mathrm{SE}=$ stander error $\quad \mathrm{Me}=$ mean 
The results of Delayed Type Hypersensitivity (DTH) in the present study may indicated that the CFSAgs elicited cell mediated immune response in immunized animals, since DTH is the essential type of CMT and it is mediated by CD4+Tcells and CD8+Tcell cytokines production, these evidence was supported idea that mentioned by $(8,9)$, who reported that Candida CFAgs and Candida CFAgs were stimulated CMI. The induction DTH reaction in animals immunized with CFSAgs in the present study may be due to the protein nature of extracellular secretion of S.aureus which is considered a good stimulator of cell mediated immune responses, these observation was supported the idea that recorded by (10).who explained that S.aureus lipoteichoic acid synthesis, a predicted membrane protein ,was release into the culture supernatant. The differences between mean values of the skin thickness against CFSAgs and SSSAgs in the present study may be due to antigen specifity and protein concentration in both antigens which may be high in the SCFAgs .The present finding showed that the CFSAgs also elicited humoral immune response and this evidence indicate that this Ags which are containing extracellular production of S.aureus are a better immunogen that stimulated both arms of immune responses. In addition, other signals, including IL-17, are critical for the production of $\mathrm{KC}$ and MIP-2 and for the subsequent recruitment of PMNs to a site of cutaneous $S$ aureus infection (11).In the present study, we investigated the depression of immune response by anticancer drugs, mitomycin C (MMC) induced diminishing in the mean values of skin thickness in animal immunized with CFSAgs and at the same time treatment with MMC as comparing with other immunized groups, this result suggests that MMC induced immunosuppression, these data are in line with previous results by other workers showing that immunosuppression are critically induced by anticancer drug mediated cell death (12).(13),suggested that MMC-treatment induces irreversibly suppressive DCs by induction of apoptosis. On the base of above evidence and our result of DTH, we suspected that the immunosuppression inducing by MMC may be due to decrease production of cytokines as a result of apoptosis of professional. The present investigation also showed that immunized animals treatment with MMC revealed low antibody titers as comparing with other immunized groups, these result may gave indication that MMC depresses humoral immune response.

\section{Clinical signs and bacterial isolation:}

The current results showed that the animals of non-immunized infected and MMC treatment -infected groups were died during (18- 72) hrs post inoculation with severe clinical signs and heavy bacterial isolation from internal organs, particularly in MMCinfected animals which showed high mortility rate during the first $18 \mathrm{hr}$ postinfection with very sever heavy bacterial isolation. while immunized animals treated or non-with MMC and showed good healthy post-bacterial challenge during the course of the experiment with absent or mild to moderate bacterial isolation from internal organs. The death of all non-immunized and MMC treatment animals during (18-24) hrs post challenge may be indicated the bacterial strains using in the present study are highly virulent factors that facilitated the attachment, colonization , avoid host defense mechanisms and dissemination from site of inoculation into internal organs and induced septic shock and death of the animals, these result are in accordance with previous results that explained that S.aureus generate adenosine to promote their survival during host infection through completely suppress immune responses(14). (15), suggest that S.aureus and other Gram-positive pathogens increase extracellular concentrations of the potent immunosuppressive molecule adenosine and, through this mechanism, are 
likely able to perturb immune defenses and promote their survival in host tissues.

\section{Pathological examination:}

\section{Gross examination:}

Infected The Gross examination of the internal organs of control challenged died mice during the first 18-24 hrs. post challenge demonstrated severe congestion of those organs, while no clear gross lesions were reported in examined organs of immunized challenged animals.

\section{Histopathological examination:}

\section{Animal died during 18-72 hr post infection.}

1.liver :The main lesions in the liver of infected animal treated with MMC characterized by dilatation and congestion of central veins and sinusoids with neutrophils in their lumen as well as single apoptotic of hepatocytic cells(fig:1). In addition to large area of coagulative necrosis characterized by eosinophilic cytoplasm of hepatocytic cells and pyknotic or disappear of their nuclei together with neutrophils infiltrated the necroticarea .,there are multiple aggregation of neutrophils scatter in the liver parenchyma Necrotic of hepatocytic cells and neutrophils scatter in liver parenchyma were also reported in the liver of control positive group,in addition to dilate of sinusoids and central veins with neutrophils in their lumens .

Spleen: The infected animal treatment with MMC expressed fibrin networks deposition in red pulp of their spleen which were infiltrated with neutrophils(Fig:2), together with abscess formation in the capsular layer that extended into the spleen parenchyma and proliferation of megakaryocytes in red pulp. The dilated and congestion of blood vessels which appear as cystic like structure filled with the neutrophils were the main lesions in white pulp of spleen of control positive animals .The microscopic examination of the spleen revealed fibrin deposition infiltrated with neutrophils in capsular area in control positive group. These lesions were more extensive in infected animals treatment with MMC .these lesion extended into capsular region of the pancreas.

Lung: The lung of control positive group expressed congestion of blood vessels with neutrophils in their lumen as well as in the alveolar space and in the intera alveolar septa and wall of blood vessels. But these lesion were more extensive in the lung of infected animals treatment with MMC which also express severe suppurative reaction with fibrin deposition in the airspace and a round bronchioles(Fig:3).

Brain: the histopathological examination of brain of control positive group showed congestion blood vessels with neutrophils in their lumen in the brain parenchyma,(Fig:4), the lesions in brain of infected treatment animals with MMC characterized by softing area in white matter that appear as cavity filled with RBCs and neutrophhils.

Kidney: The main lesion in the kidney of control positive group characterized by neutrophils infiltration of capsular region and these reactions extended into interstitial tissues. In other section, fibrin networks deposition between renal tubules as well as neutrophils infiltration(Fig:5)in addition to acute cellular degeneration characterized by vacuolation and desquamation of epithelial lining cells of renal tubules. Large abscess was recorded in the capsular region of the kidney of infected animal treatment with MMC which died at $72 \mathrm{hrs}$ post infection and these abscess extended into kidney parenchyma in which the lesion characterized by large area of aggregation necrotic neutrophils and cellular depress surrounded by fibrous connective tissues

Infected animal immunized with CFSAgs Prpoliferatoin of kupffer cells with small granulomatous lesion were reported in the liver of animal immunized with CFSAgs at day 3 (Fig:6) and day 4 post-infection together with large mononuclear cells mainly lymphocytes aggregation around 

AL-Qadisiya Journal of Vet.Med.Sci.
Vol./12
No./1
2013

airway of the lung at day3 but these lesions

were more ecxtensive at day 10 postinffection noclear lesion were seen in the hearT, and brain but marked hyperplasia of whitr pulp of the spleen was seen at day 10 post infection.

\section{Infected immunized animals treatment with MMC.}

\section{At ( 3)days post infection:}

The microsdopic section showed granulomatous lesion consisting from aggregation macrophages and lymphocytes in liver and kidney (Fig7) of animals in these group at day 3 post-infectiion,in addition ,inflammatory cells mainly macrophages in the alveolar space and congestionn of blood vesseks with neutrophils in their lumen in the lung.

At (10) days post infection:

There were marked lymphoid tissues hyperplasia of white pulp and hyperplasia of endothelial lining cells of central arteries as well as proliferation of mononuclear cells around sinus tract form cord-lik appearance particularly at day 10 post -infection ,in addition severe mononuclear cells aggregation in the wall of blood vessels and in the wall of the alveoli(Fig:8).

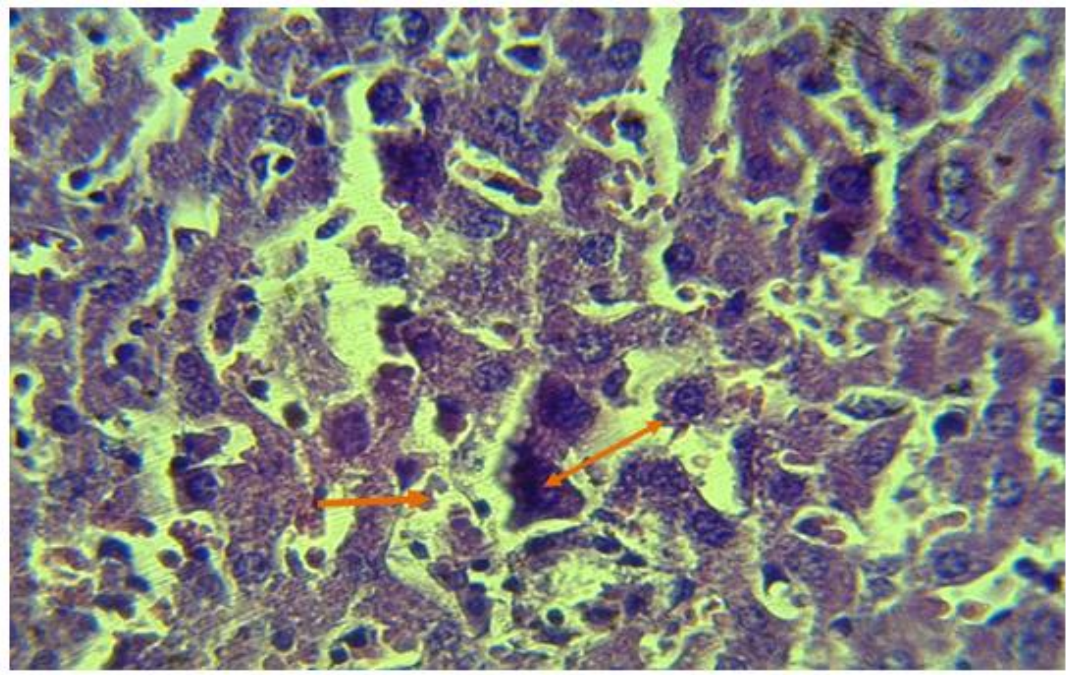

Fig:1.Histological section in the liver of animal treated With MMC at $24 \mathrm{hr}$ postinfection shows dilated and congestion of sinusoids With neutrophils in their lumen as well as apoptotic cells $\longleftrightarrow$ (H\&Estain 40X).

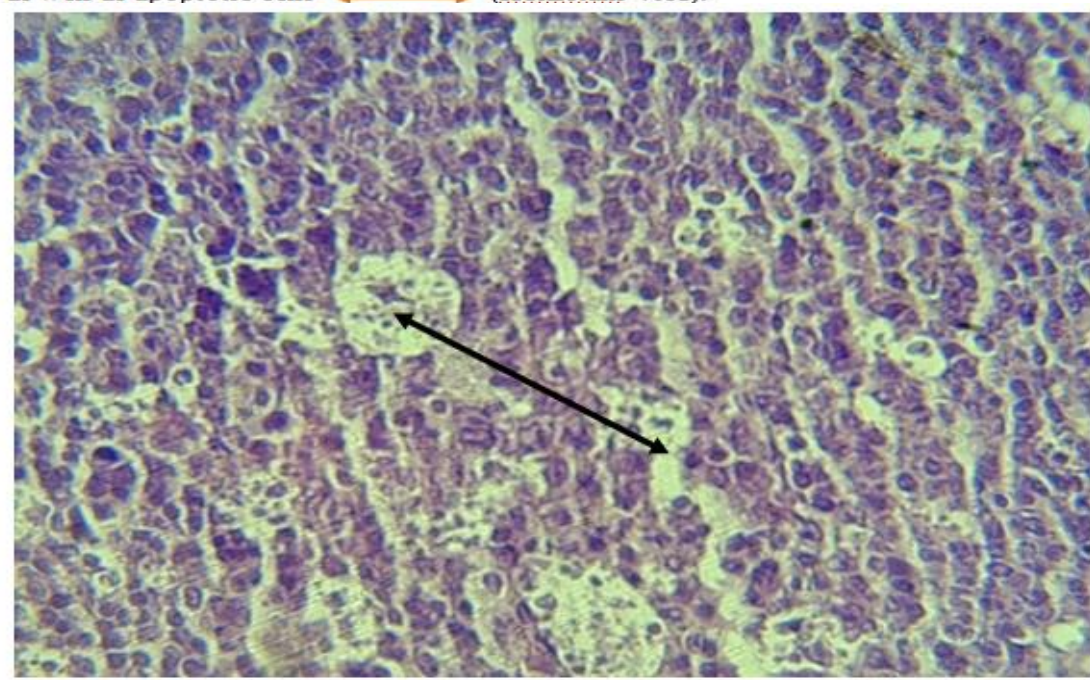

Fig:2 Histological section in the spleen of animal at $24 \mathrm{hrs}$ post infection shows congestion blood vessels in white pulps with neutrophils in their lumen as well as in congested sinuses of red pulp $\longleftrightarrow$ (H\&E stain $40 \mathrm{X}$ ). 
$\begin{array}{llll}\text { AL-Qadisiya Journal of Vet.Med.Sci. } \quad \text { Vol./12 } & \text { No./1 }\end{array}$

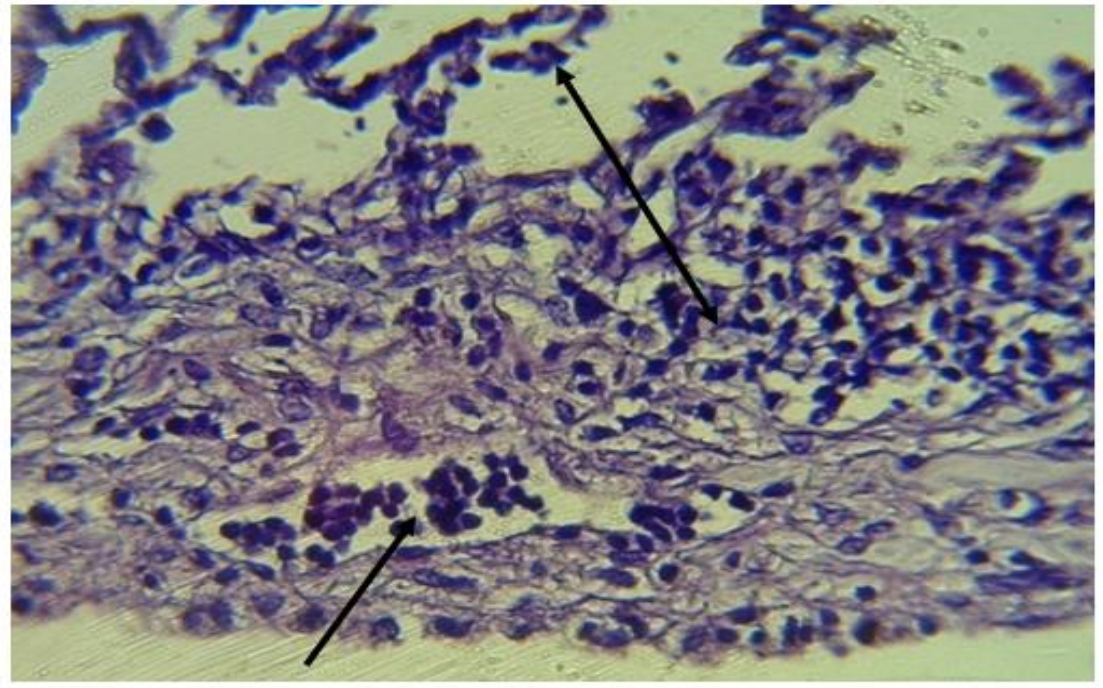

Fig:3Histological section in the lung of animal treatment with MMC at $24 \mathrm{hr}$ post infection shows thickness of inter alveolar septa, fibrin network and neutrophils in the alveolar space $\longleftrightarrow$ and in the lumen of blood vessels $\longrightarrow$ (H\&Estain $40 \mathrm{X}$ ).

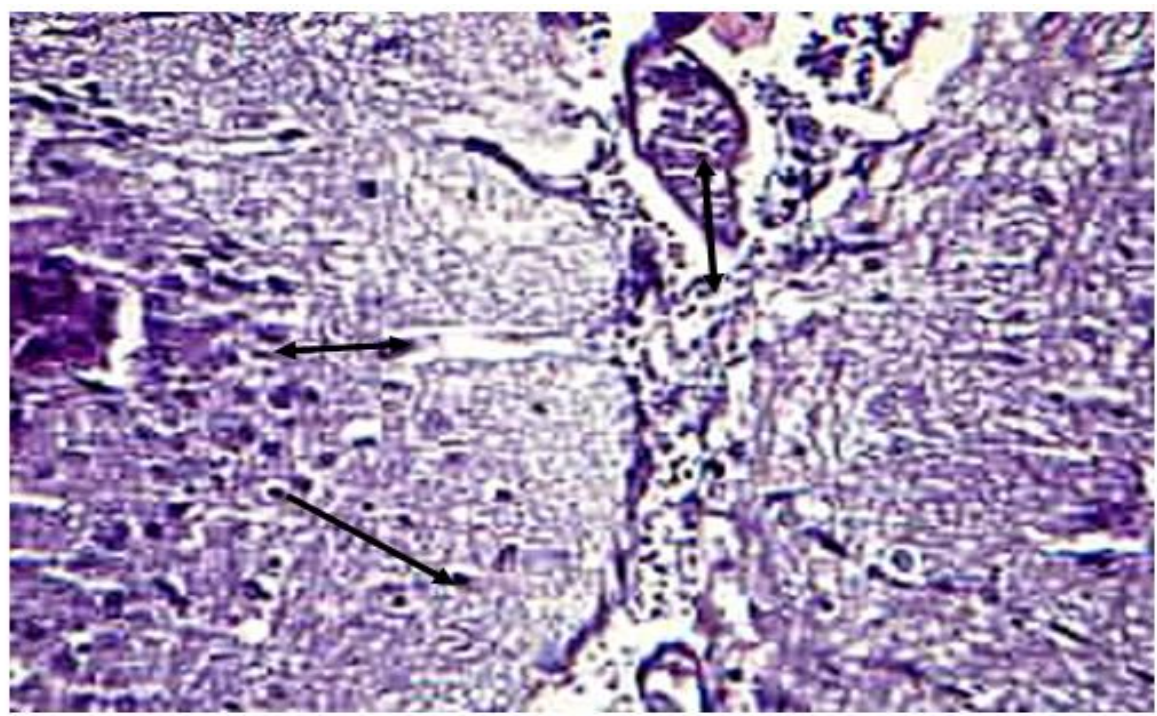

Fig:4 Histological section in the brain of animal at $24 \mathrm{hr}$ post-infection shows congestion of blood vessels in brain parenchyma $\longleftrightarrow$ with neutrophils in their lumen $\longrightarrow(\mathrm{H} \& \mathrm{E}$ stain $40 \mathrm{X})$. 


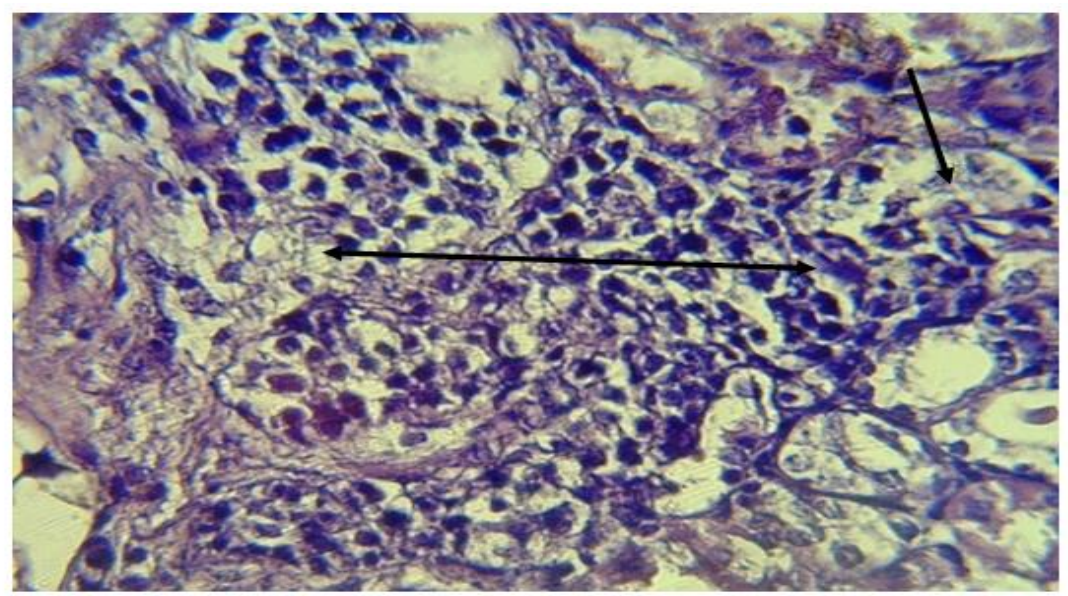

Fig:5 Histological section in kidney of animal at $24 \mathrm{hr}$ post infection shows network of fibrins deposition in the interstitial tissues and inflammatory cells infiltration mainly neutrophils $\longleftrightarrow$ as well as acute cellular degeneration of renal tubules (H\&E stain 40X).

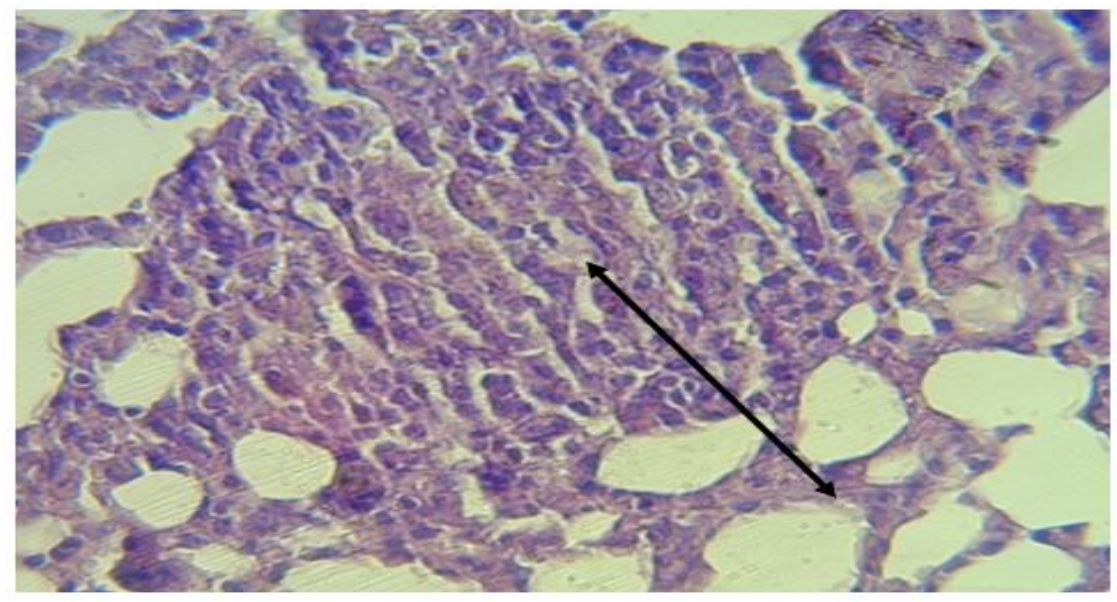

Fig:6Histological section in lungof immunized animal at 10days post infection shows marked mononuclear cells aggregation around airways $\longleftrightarrow$ (H\&E stain $40 \mathrm{X}$ ).

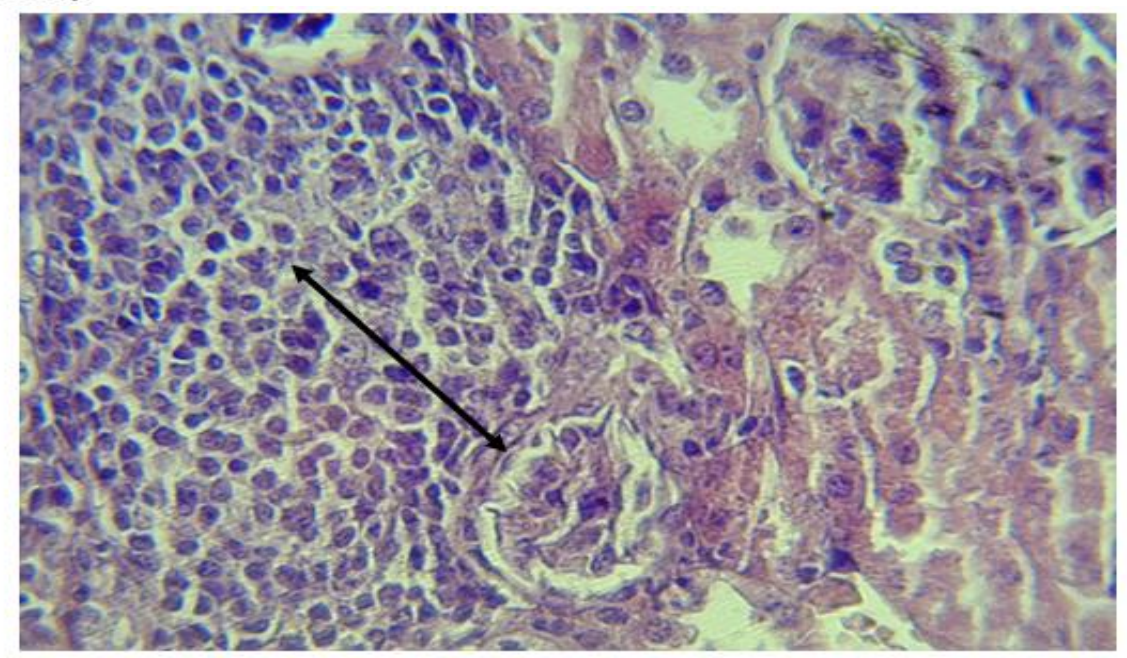

Fig:7 Histological section in the kidney of immunized animal treatment with MMC at 3 days post infection shows granulomatous lesion in the interstitial tissues with thickining of the glomerular wall due proliferation of fibrous connective tissues $\longleftrightarrow$ (H\&Estain 40X). 


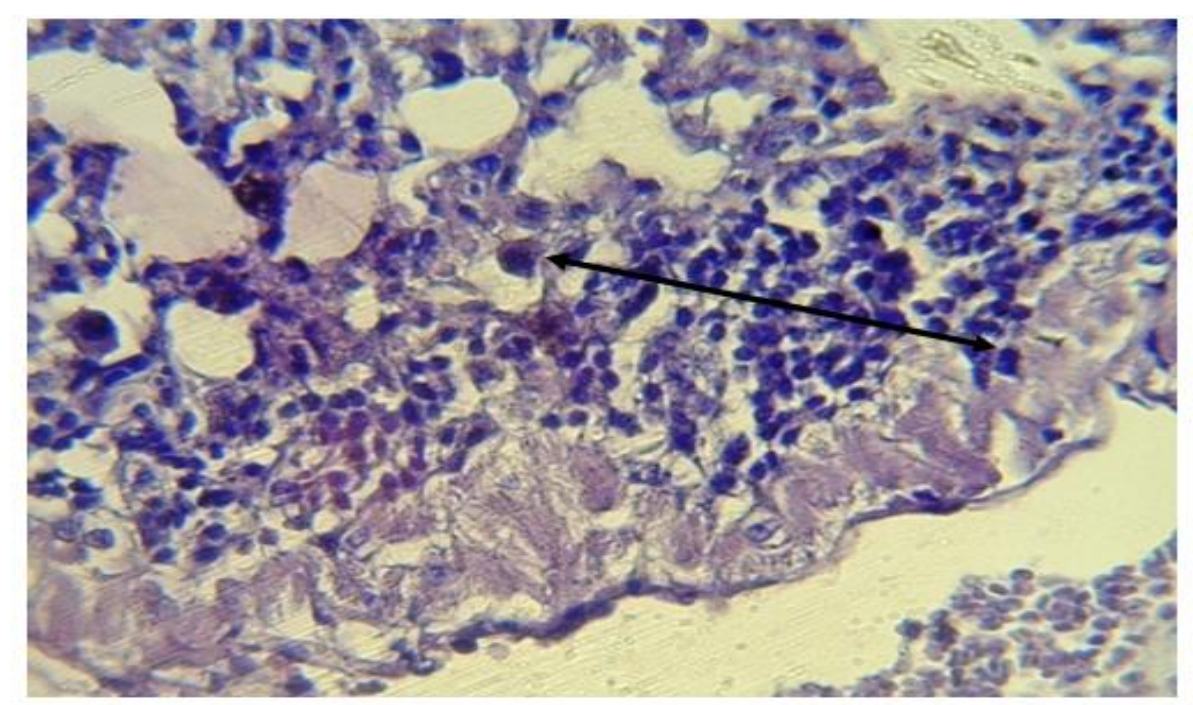

Fig:s Histological section in lung of immunized animal treatment with MMC at 10 days post infection shows aggregatiob of mononuclear cells around conggested blood vessels which showed hyperatrophy of muscular layer and proliferation of alveolar macrophages in alveolar space (H\&Estain 40X).

The present study showed severe pathological lesion in the internal organs of control positive group ,these result may be indicated that S.areus overcome innate immune responses of the host and it was supported evidence that recorded by previous reports. The innate immune system plays an integral role in determining the outcome of the infection. (16).The establishment of staphylococcal abscesses with liquefaction necrosis represents the sum of all pathogenetic events implemented by the activity of virulence factors, bacterial molecules sampled by the host and the corresponding host responses(17).Our results explained that mild pathological lesions in the internal organs of immunized group characterized by present small granulomatous lesion in the livers and these result may be indicated that the CFSAgs provide protective immunity that destroyed large number of pathogens during dissemination from inoculated site till reach the internal organs, these evidence was in coincidence with other our results. These data are in agreement with (9),

\section{Reference}

\section{Steinman,R.M.,and Mellman I.(2004).} Immunotherapy bewitch, bothered and bewildered no more. science 305:197-200.

2. Deleo FR, Chambers HF (2009). Reemergence of antibiotic-resistant Staphylococcus aureus in the genomics era. J Clin Invest.; 119(9): 2464-2474.

3. Stranger-Jones YK, Bae T, Schneewind $\mathrm{O}(2006)$. Vaccine assembly from surface proteins of Staphylococcus aureus. Proc Natl Acad Sci U S A. Nov 7;103(45).
4. Cruickshank, R.; Duguid, J.P.; Marmion, B. and Swain, R.H. (1975). "Medical Micro-biology, A Guide to the Laboratory Diagnosis and Control of Infection" $12^{\text {th }} \mathrm{Ed}$. Vol. 2.

5. Miles, A.A.; Misra, S.S. and Irwin, J.O. (1938). The estimation of the bactericidal power of blood. J. Hyg. Camp., 38: 739-749.

6. Hudson, L. and Hay, F.C. (1980). "Practical Immunology". $3^{\text {rd }}$ Ed. Blackwell Scientific Publication, Oxford. London. 
$\begin{array}{llll}\text { AL-Qadisiya Journal of Vet.Med.Sci. } & \text { Vol./12 } & \text { No./1 }\end{array}$

7. Herbert, W.J. (1978). Passive heamagglutination with special reference to the tanned cell technique. Ch. 20, In : Weir, D. M. "Handbook of Experimental Immunology". ( $3^{\text {rd }}$ Ed.) Vol. II, Cellular Immunology. Blackwell Scientific Publication, 20: 1-20.

8. Hayder. N. A. (2010). Cryptococcosis: Immunopathological study in mice immunized with Cryptococcus neoforman antigens and Diagnostic study in human. Thesis faculty of veterinary medicine ,Baghdad university.

9. Mohammed. M. A. (2012). The influence of culture filtrate of Candida albicans and Cryptococcus neoformans antigens on pathogenesis of $C$. albicans Isolated from mastitic milk and milkers . Thesis faculty of veterinary medicine ,Baghdad university.

10. Oku, Y., et al. 2009. Pleiotropic roles of polyglycerolphosphate synthase of lipoteichoic acid in growth of Staphylococcus aureus cells. J. Bacteriol. 191: 141-151.

11. Cho JS, Pietras EM, Garcia NC, et $\mathrm{al}(2010)$. IL-17 is essential for host defense against cutaneous Staphylococcus aureus infection in mice. J Clin Invest.;120(5).

12. Shah, N.; Dizon, D.S(2009). Newgeneration platinum agents for solid tumors. Future Oncol., 5, 3342.

13. Jiga L, Ehser S, Kleist C, Opelz G, Terness P(2007). Inhibition of heart allograft rejection with mitomycin C-treated donor dendritic cells. Transplantation 83:347-350.

14. Thiel, M., C.C. Caldwell, M.V. Sitkovsky. (2003). The critical role of adenosine A2A receptors in downregulation of inflammation and immunity in the pathogenesis of infectious diseases. Microbes Infect. 5:515-526.

15. Németh, Z.H., B. Csóka, J. Wilmanski, D. Xu, Q. Lu, C. Ledent, E.A. Deitch, P. Pacher, Z. Spolarics, G. Haskó. (2006). Adenosine A2A receptor inactivation increases survival in polymicrobial sepsis. $J$. Immunol. 176:5616-5626.

16. Takeuchi O , Hoshino K, Akira S (2000). J Immunol165:5392-5396.

17. Novick, R. P. (2003). Mobile genetic elements and bacterial toxinoses: the superantigen-encoding pathogenicity islands of Staphylococcus aureus. Plasmid 49:93-10. 


\section{التغيرات المرضية المحدثة بواسطة بكتريا المكورات العنقودية الذهبية في الفئران المخفضة مناعياً باستخدام علاج المايتومايسن س المسئة (Mitomycine C)

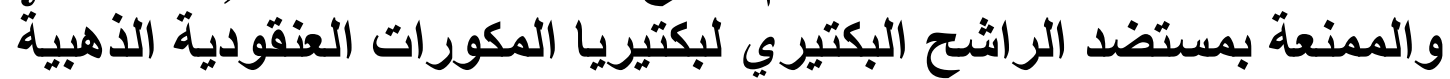

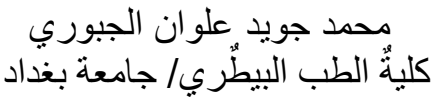 حسان هادي خورشيد ألبياتي الخلاصة}

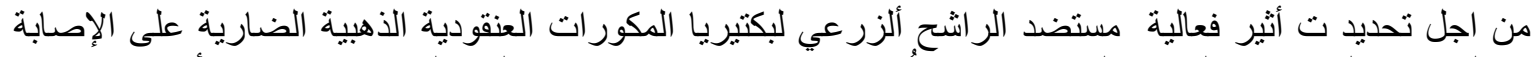

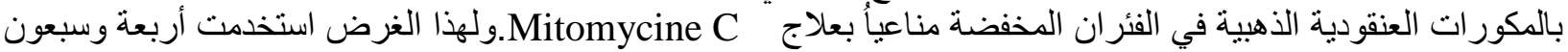

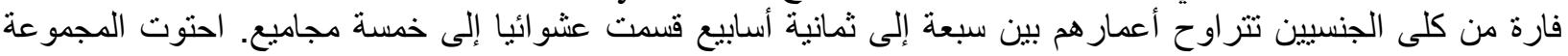
الاولئ تحتوي على 16 فارة ومنعت (0.4 مل) بمستضد الراشح البكتيري للبكتيريا المكورات العنقودية الذية الذهبية

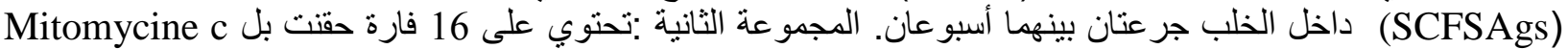

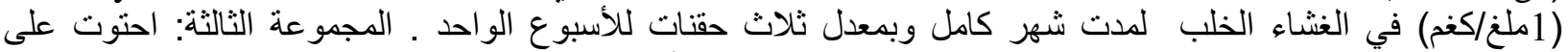

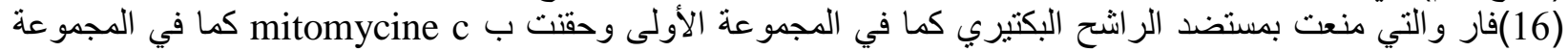
الثانية. المجموعة الرابعة : ضمت هذه المجموعة (10) فار و التي تعتبر كمجموعة سيطرة موجبة حقنت

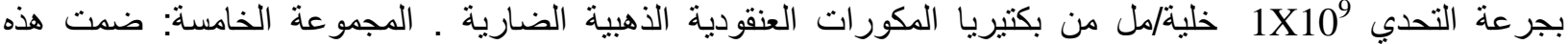

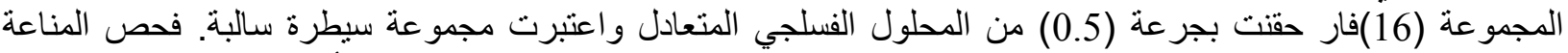

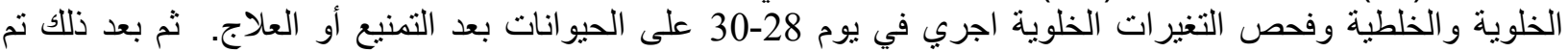

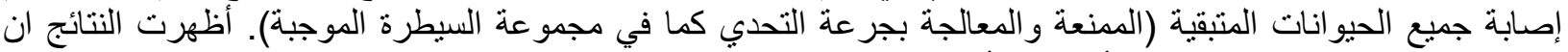

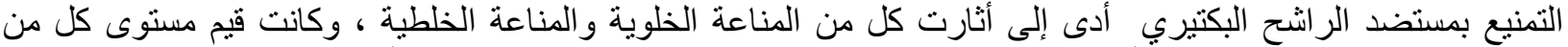

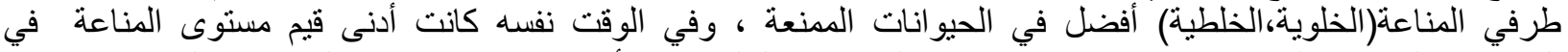

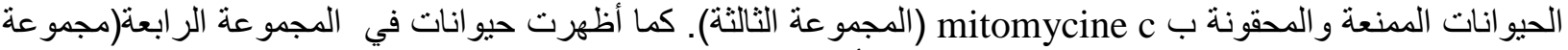

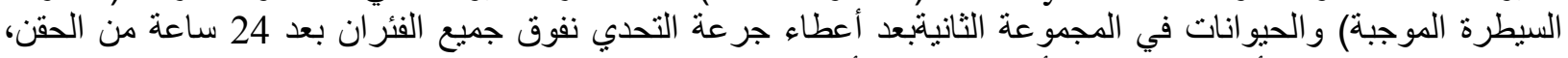

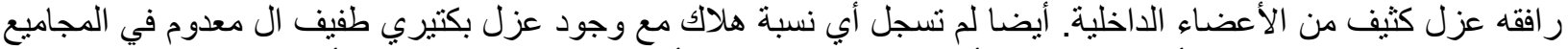

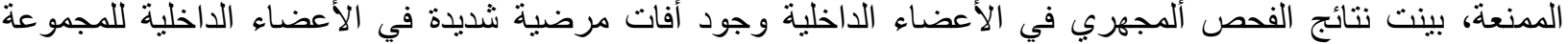

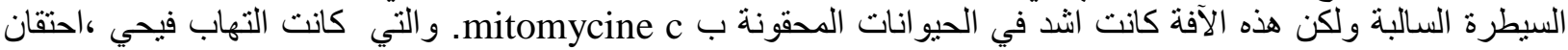

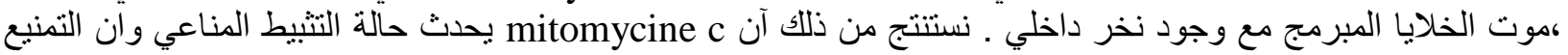
ب مستضد الر الثح البكتيريب لبكتيريا المكورات العنقودية الذهبية (SCFSAgs) يؤدي إلى تحسين الاستجابة المناعية في الحيو انات التي تعاني من تثبيط مناعي. 